\title{
'brightening the dreary existence of the Irish peasant': Cinema transforms leisure in provincial Ireland
}

\author{
Denis Condon*
}

School of English Media and Theatre Studies, National University of Ireland, Maynooth, Ireland

Examination of the institutionalization of cinema in Sligo, Ireland, demonstrates the uniqueness of local conditions that led to cinema's second birth. When the Sligo Picture Theatre opened in late 1911, it was one of the first dedicated film venues in Ireland outside the major cities, but it already had to compete against a rival film show run by the Catholic Church. While the Picture Theatre was an expansion of the commercial interests of a family in the photographic trade, the church's initial interest in cinema arose from its temperance organization's need to have evening activities for teetotallers. As labour militancy increased with the introduction of trade unions to Sligo at precisely the same time as cinema, the church and business owners of the town saw the value of cinema in distracting the working class from socialist ideas and effective organization in their own interests. As a result, cinema's institutionalization in Sligo was largely determined by the priorities of existing institutions.

Keywords: second birth of cinema; early cinema; intermediality; cinema institution; cinema building boom; cinema history and film history; Irish on film; peasants on film; Kalem; population of Ireland; Sligo, Ireland; temperance; Irish Catholic Church; working-class leisure; nationalism; trade unionism.

*Email: denis.j.condon@nuim.ie

\section{Second births, revivals, centenaries: Some untimely considerations}

Writing of the second birth of cinema in Ireland in the early 2010s is to be irresistibly reminded that Karl Marx famously amended Hegel's contention 'that all great world-historic facts and personages appear, as it were, twice', by arguing that this development follows a generic pattern, occurring 'the first time as tragedy, the second as farce' (Marx 594). In 2012, Ireland experienced the first year of a decade-long 'season of centenaries', commemorating events of national and international significance from the introduction of the Third Home Rule bill in 1912 through Ireland's involvement in the First World War and finishing with the Irish Civil War of 1922-23, with the 2016 commemoration of the Easter Rising forming the symbolic core of events. This rolling series of events represents an extended dialogue not only between scholars and the past but also among the wider public. It has also been the occasion for the first real scholarly analysis of memory in relation to Ireland with the appearance of the first of a projected four-volume series of essay collections called Memory Ireland (Frawley 2011). Although this essay does not wish to hasten a widespread flight from the past that may be the result not of traumatic memory but of centenary fatigue, it will argue that the period between 2011 and 2014 marks the centenary of the 'constitution' of cinema as an institution in Ireland.

To use the phrase 'constitution' is to adopt the terminology suggested by André Gaudreault and Philippe Marion in their essay 'A medium is always born twice...' (2005). For Gaudreault and Marion, the historical experience of cinema is exemplary of a double birth through which all media pass to attain an autonomous identity. Initially, the medium's basic apparatuses appear in a 'first birth'; this is followed by the medium's emergence as ways of using these apparatuses are defined; and finally, a 'second birth' sees the medium constituted as an autonomous institution. However useful such a schema might be in providing a model applicable to media more generally, aspects of their discussion of cinema certainly offer explanatory power in the consideration of the institutionalization of cinema in Ireland. For one thing, the phrase 'second birth' not only captures something of the suddenness of the resurgence of cinema in the early 1910 s in Ireland but also resonates with a society in which nationalist discourses of cultural and 
political revival were common. More particularly, the date they suggest for cinema's second birth, 1910, seems broadly, if not precisely, applicable to the case that will be examined here. ${ }^{1}$

Certain reservations must be noted. As an organic metaphor, birth is an inappropriate and even misleading descriptive term for developments in media. Gaudreault and Marion acknowledge this when they argue that the term 'second' birth is meant to undermine the "hagiographic mythology that has the "infant medium" being delivered to our doorstep one fine morning by some turn-of-the-century stork' (4-5). Although positing a second birth for cinema may deemphasize the medium's first birth and fraught paternity, the continued use of the birth metaphor may just as easily create another moment at which to search for 'fathers'. If the birth metaphor must be used, the second birth of cinema should be considered in the plural - like the multiple first births in France, the United States, Germany and Britain: the second births really constituted a baby boom. The arrival of cinema as a cultural institution raised questions of legitimacy - of whether this was a passing fad like the recent boom and bust of roller-skating rinks or truly a part of national culture, a question of particular urgency in Ireland of the period and of sibling rivalry, of where the new entertainment would fit with existing amusements, which would be preferred, which displaced, and so on. The institutionalization of cinema happens at different times in different places and can look very different from the local level than it does from the global perspective of cinema as a whole.

Therefore, this essay will be a work of local cinema history, investigating the moment at which the cinema institution was constituted in the town of Sligo on Ireland's northwest coast. As a work of cinema history rather than film history, it largely endorses the arguments of writers who stress the new cinema history's emphatic rejection of textual readings of films or even film reception as a privileged source of information about cinema's past (Maltby and Stokes 2007; Maltby 2011). Cinema did not become institutionalized in Sligo because of any one film or group of films, and an analysis of any or even all the films exhibited would be of little use in determining the role of cinema in the town.

Nevertheless, this essay will refer to certain films, particularly the 'O'Kalem' films - the almost 30 films made mainly for the New York-based Kalem company but also for other US production companies in Ireland in the early 1910s by Sidney Olcottt, Gene Gauntier and their collaborators. These films were particularly rhetorically important at precisely the moment that cinemas were beginning to proliferate in Ireland because they showed that cinema could offer representations of the Irish that were widely regarded by the Irish as not only acceptable but also positive enough to form part of the celebration of Irishness at such important moments as St. Patrick's Day. ${ }^{2}$ Research on the institutionalization of cinema in Sligo repeatedly uncovers significant showings of the 'O'Kalem' films, including Rory O'More (1911) and the 'O'Kalems' adaptation of Dion Boucicault's famous Irish stage melodrama The Colleen Bawn (1911). These films show how extraordinarily pervasive stereotypes of the Irish that could - in different hands - be affectionate, subversive or offensive were reproduced and then relayed on to cinema audiences. A material way in which the 'O'Kalem' films impact on the industrial and political context of Ireland in the early 1910s comes in the guise of the peasant. The Colleen Bawn's Myles $\mathrm{Na}$ Copaleen is the archetypal drunken Irish peasant with his instantly recognizable costume of felt hat, tailcoat and knee breeches and the barrel of whiskey he has cooked up on his own secret still (Figure 1). This will become more apparent as we turn to a discussion of one aspect of cinema's baby boom - the boom in picture house construction/conversion - by looking at the process that brought the cinema to one Irish town. 


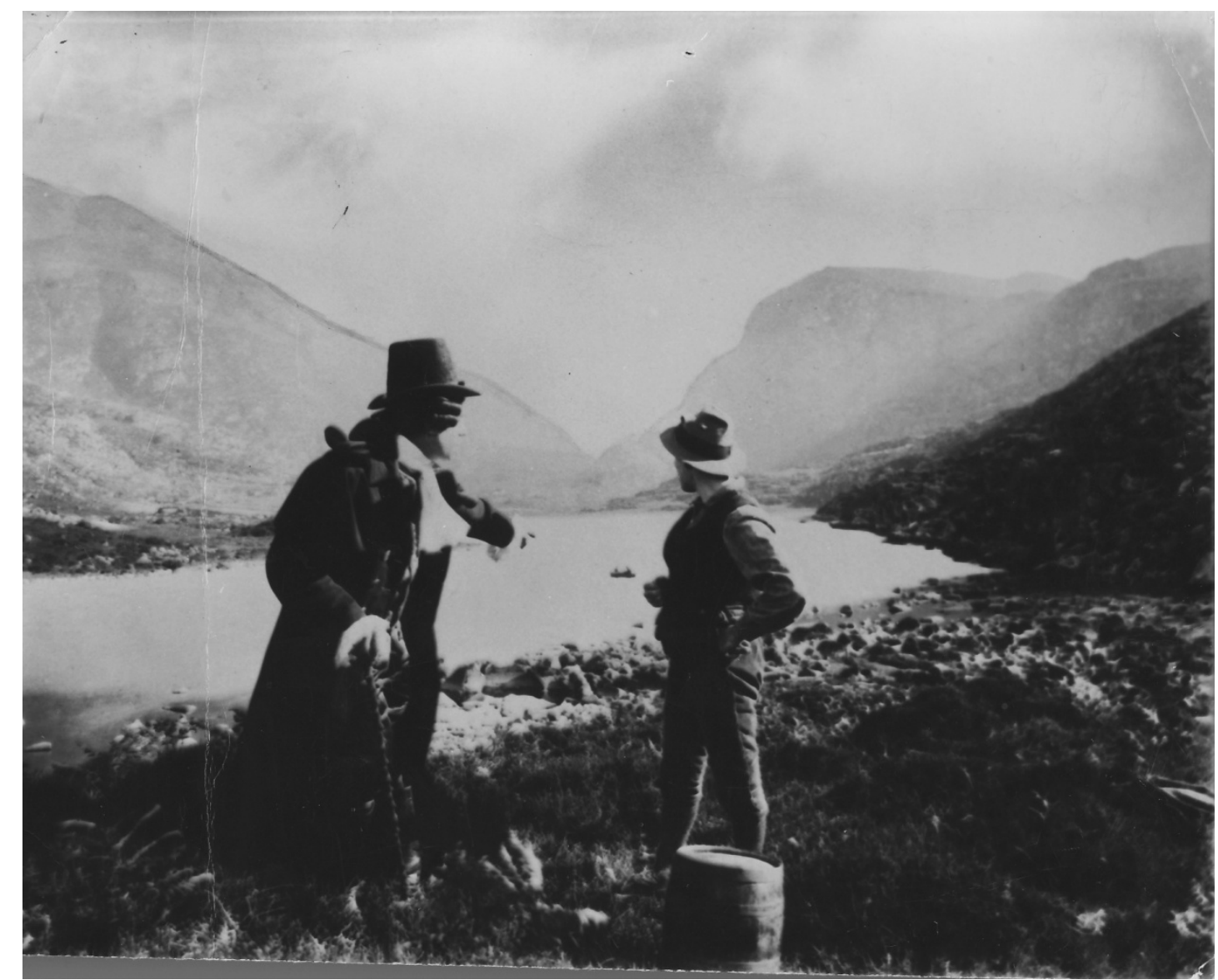

Figure 1. Still from The Colleen Bawn (Kalem, 1911), shot on location at the Gap of Dunloe, near Killarney, Co Kerry. The figure on the right is Myles $\mathrm{Na}$ Copaleen. Courtesy of the Trustees of Muckross House (Killarney) Ltd.

\section{Battling not building working-class sociability: Instituting cinema in Sligo}

Writing in the British cinema trade journal Bioscope in November 1913, Ireland correspondent 'Paddy' offers insight into the Irish cinema boom. Noting the surprising penetration of the cinema into the Irish provinces, he comments: 'At first progress was slow, and halls were opened gingerly in only the largest provincial towns. Now things are reversed. Small towns - towns of roughly only 1,000 inhabitants - have been invaded by the all-conquering cinema' (Paddy 854). The period he described was very short: the arrival of the cinema as a permanent feature of not only of Irish cities and but also of small towns and rural areas began in 1911 and continued until 1914, when the First World War slowed the seemingly ever-increasing pace in the construction of ever-larger cinemas. In a very short period after 1910, the way that many Irish people spent their leisure time changed fundamentally. Dozens of cinemas sprang up in the centres and suburbs of the large Irish cities of Dublin and Belfast to meet the burgeoning demand for moving pictures, but the changes to the way people spent their leisure time were particularly clear in provincial towns. The larger populations of the cities supported many types of entertainment activity that could be enjoyed any night of the week, but in towns and rural areas, professional and even amateur entertainment was typically sporadic and did not encroach very significantly on the business of provincial Ireland's main indoor leisure provider: the pub. By 1914, however, an extraordinary transformation had taken place not only in the cities but also in Irish towns of any size, where for the first time ever, people could, if they could afford it, attend a nightly, professionally made entertainment, and in many places, they could choose to which of the town's moving-picture shows they would go. Paddy concludes: 'There is little doubt that the cinema can do a great deal towards brightening the dreary existence of the Irish peasant' (854). 
Although Paddy 's remarks certainly evidence an important development as it was occurring, many Irish people did doubt the benefits of the cinema at a time when what one did in one's leisure time was becoming increasingly politicized. The focus of much of the political energy in Ireland in the last decades of the nineteenth century and first decades of the twentieth century was on Home Rule, which did not represent full independence from Britain but a high degree of legislative autonomy, including a parliament that would sit in Dublin. As the looming reality of Home Rule stimulated and polarized political activity among nationalist and unionist communities - these political divisions mapped closely, but not exactly, onto the sectarian division in a population that the 1911 census shows to be 73 percent Catholic and 27 percent Protestant - the cultural flowering of the Irish Revival reached into every parish in the country, epitomized in the work of the Gaelic League and the Gaelic Athletic Association, organizations working particularly in the areas of the revival of the Irish language and of Gaelic sports. For these groups, as well as for writers of the literary revival, the cultural specificity of Ireland - a crucial element in the rhetorical claims for self-government - was a process of retrieval of cultural forms that predated British colonization and of rejection of much contemporary popular culture that was seen as bearing the taint of empire. Despite the potency and popularity of such ideas, the Irish population as a whole certainly did not reject the cinema out of hand, as the harbinger and instrument of an unwelcome modernity. Indeed, local struggles over the establishment of the cinema show the sometimes surprising ways in which the cinema became a part of Irish society.

There was a geographical element to this: if the 'O'Kalems' came to Killarney in search of an authentic landscape that was largely the creation of nineteenth-century popular culture and the canny tourist promotion of Killarney (Condon 2010), for Irish cultural nationalists, other parts of the West - particularly the most inaccessible coastal fringes and islands - were privileged as the last bastions of the Irish language and customs. Both of these Wests of Ireland - the tourist and the cultural nationalist versions - existed to some degree, even if they also contained substantial elements of projection. Alongside these sparsely populated Wests were the other Wests that emerge from the historical documents of such cities and county towns as Limerick, Galway, Sligo and Tralee, where the people of the West could come together and - at least on occasion - see themselves represented on screen among cinematic representations of many other peoples and places.

These dynamics are apparent in the establishment of cinema in Sligo. Sligo was - and still is the administrative town of County Sligo, located on the northwest coast of Ireland. In the census year of 1911, it had a population of 11,167. That figure represented a modest gain of just 300 on the 1901 census, but it contrasted with the wider trend; County Sligo as a whole experienced a fall in population of 5,233, lost to emigration to Britain and the United States and to internal migration to Irish towns and cities. This was the case in all parts of the west of Ireland, and represents the increasing urbanization of the Irish population; the Irish peasant or rural dweller was in steady decline. 'The outlook, as far as the town of Sligo is concerned, is, therefore, a hopeful one,' commented the Sligo Independent's editorial writer in June 1911 (Anon. 1911a). 'The population of the towns is increasing, and the rate of decline in the country is slackening, partly owing to the fact that the drain by emigration is not so heavy as it was some years ago.' Sligo's modest attractions for those leaving the region's smaller towns, villages and rural areas included the fact that it was both a market town, to which the agricultural produce of the hinterland was brought, and a transport hub, with rail links to the larger Irish cities and a port from which such goods were exported. Sligo's port was the biggest in northwest Ireland, with particularly strong trading links with Liverpool and Glasgow. What left Sligo, though, were cattle and crops, and the town had no major industries to absorb substantial migrating populations. 

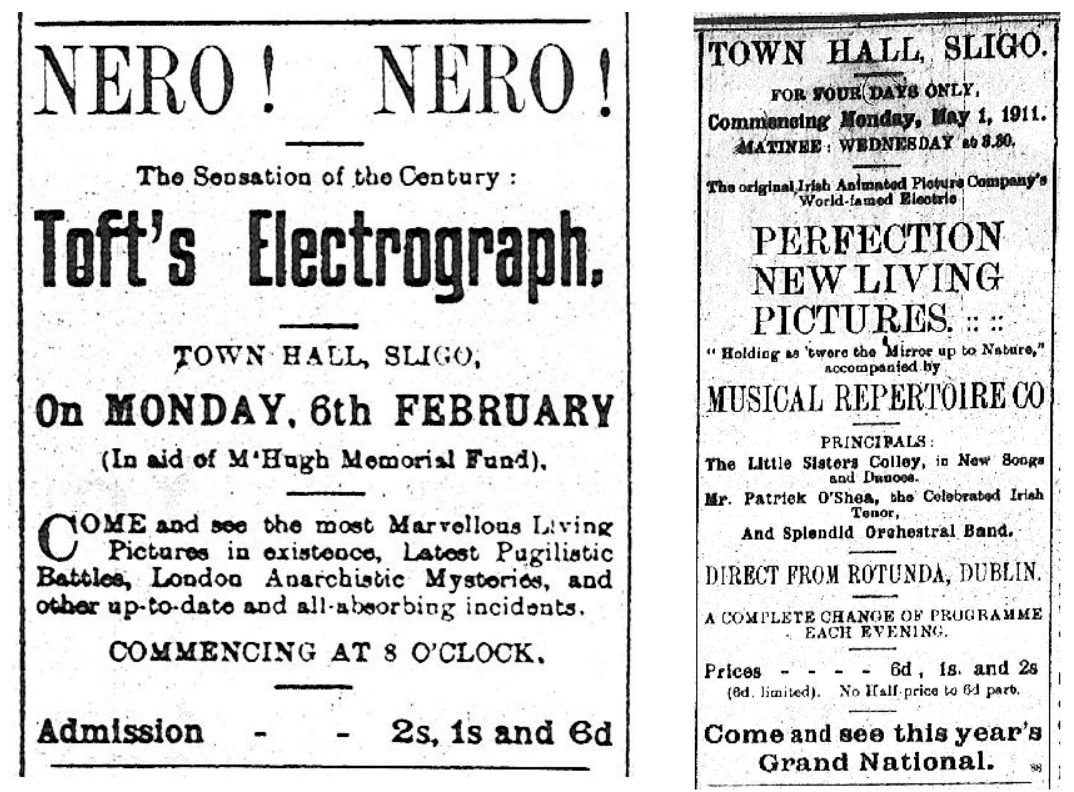

Figure 2. Film shows by travelling exhibitors John Toft and the Irish Animated Picture Company in Sligo's Town Hall in February and May 1911. Sligo Champion, 28 January 1911 and 29 April 1911.

Among the town's major public buildings was the Town Hall with its large Assembly Room, in which many visiting entertainers performed. It was usually here that itinerant impresarios mounted concerts, dramas and occasionally throughout the 1900s, film shows. In 1911, which is the important year for cinema's institutionalization in Sligo, film shows by travelling companies included fairground showman John Toft's exhibition in February of the Italian epic Nero (Ambrosio, 1909) as a benefit in aid of a monument to nationalist politician P. A. McHugh and the four-night run in May by the Irish Animated Picture Company (IAPC), the largest Irish film company of the 1900s and 1910s (Figure 2).

The IAPC's importance in the eyes of the trade was illustrated in mid-November 1911, when its managing director, James T. Jameson, became the first Irish subject of the Bioscope's Picture Personalities caricature series (Figure 3). The caricature's representation of this businessman shares much of the 'O'Kalem' films' mise en scène: located in a setting that is recognizably the tourist's Killarney, it depicts Jameson as a stage Irish peasant in knee breeches, tail coat and felt hat accessorized with a clay pipe, and accompanied by a young Irish peasant woman, or colleen (an Anglicization of cailin, the Irish word for girl). ${ }^{3}$ Here, then, we have the Irish peasant as the active agent in introducing the phenomenon that will brighten the life of the Irish peasant. The caption described him as the owner of 'many successful shows in the Emerald Isle, chief among which is the Rotunda, Dublin', with the significance of the Rotunda emphasized visually by Jameson holding a model of it in his hands. Jameson and the IAPC's connection with the Rotunda had been part of a business strategy for almost a decade by November 1911, but even as the Bioscope hailed its success, that strategy was under threat in Dublin and around the country. The Rotunda had been built in the eighteenth century as part of an entertainment complex with adjoining pleasure gardens that were intended to provide funding for the city's maternity hospital (Campbell Ross, passim). Partly as a result of this charitable function, the Rotunda was one of Dublin's most prestigious venues and as such, was one to which elite patronage could be attracted; impresarios who first exhibited there frequently advertised shows in other Irish towns as coming 'direct from the Rotunda'. A former printer and journalist, Jameson had skilfully marketed his IAPC seasons at the Rotunda so that they attracted audiences of all classes particularly the more lucrative middle classes - and shades of political opinion in the city. Even after other exhibitors had entered the business in Dublin in the late 1900s and early 1910s and demonstrated the viability of dedicated picture shows, Jameson persisted with his proven 
strategy of touring picture seasons at the Rotunda and other prestige venues - usually town halls - around the country (Condon 2008, 161-69; Rockett and Rockett 2011, 245-57). Jameson sought long-term leases on the more lucrative town hall venues, basing a manager and support staff in the towns and touring the films and variety acts on this circuit. Similar to certain public hall showmen in the North of England, he created some local resentment because the IAPC shows effectively booked up the venues where both professional touring companies and local amateur drama and music groups would have mounted their entertainments (Brown 2004; Condon 2010). 


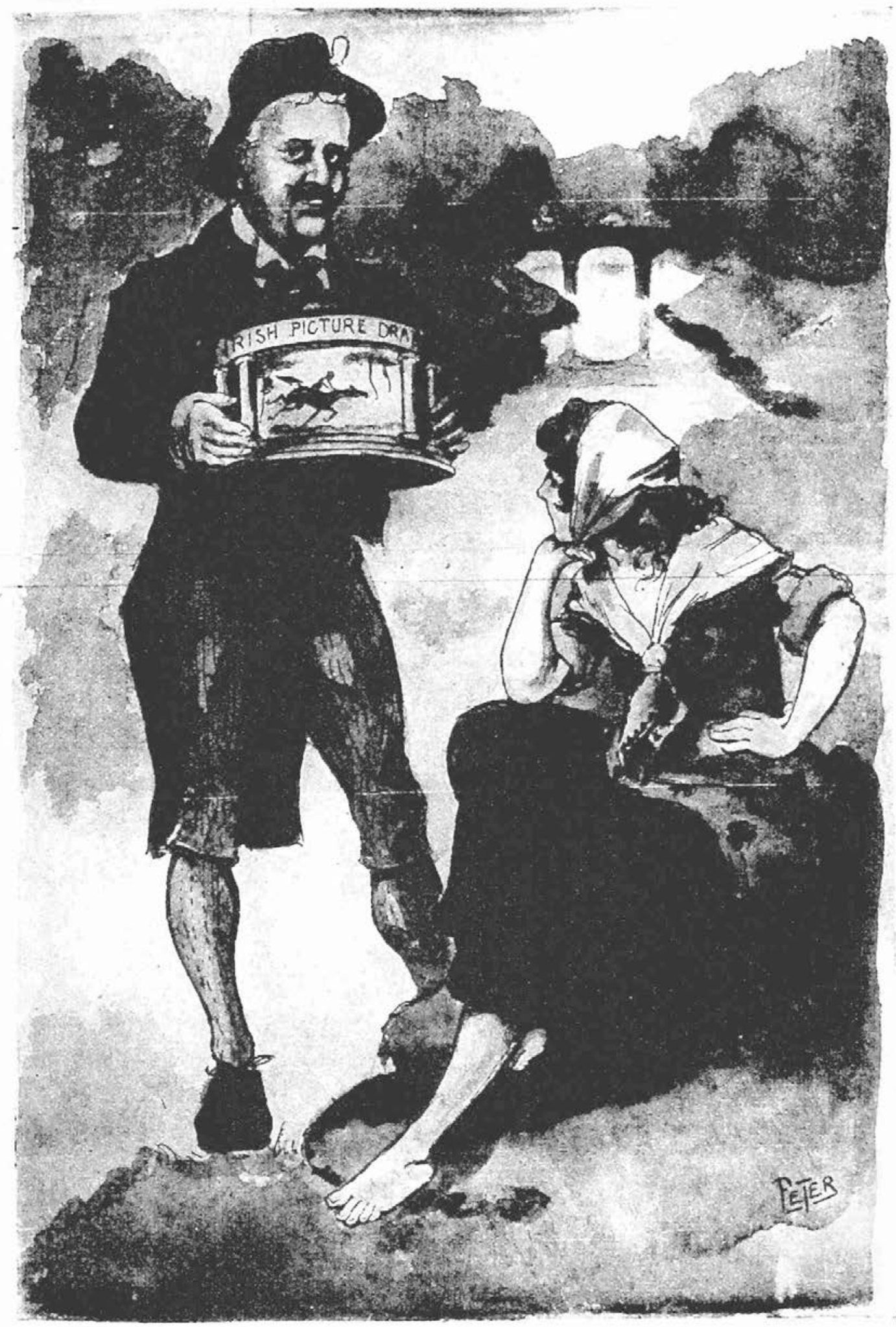

Figure 3. Caricature of James T. Jameson as peasant. Bioscope, 16 November 1911.

Jameson was not, however, able to add the Town Hall in Sligo to the IAPC circuit because he faced substantial locally based competition. When the company returned for another four-night run beginning on New Year's Day 1912, it was not the only film show on offer, and its advertisement appeared alongside others for the Sligo Picture Theatre, which was one of the first dedicated cinemas in Ireland outside the cities and which had not existed when the IAPC had 


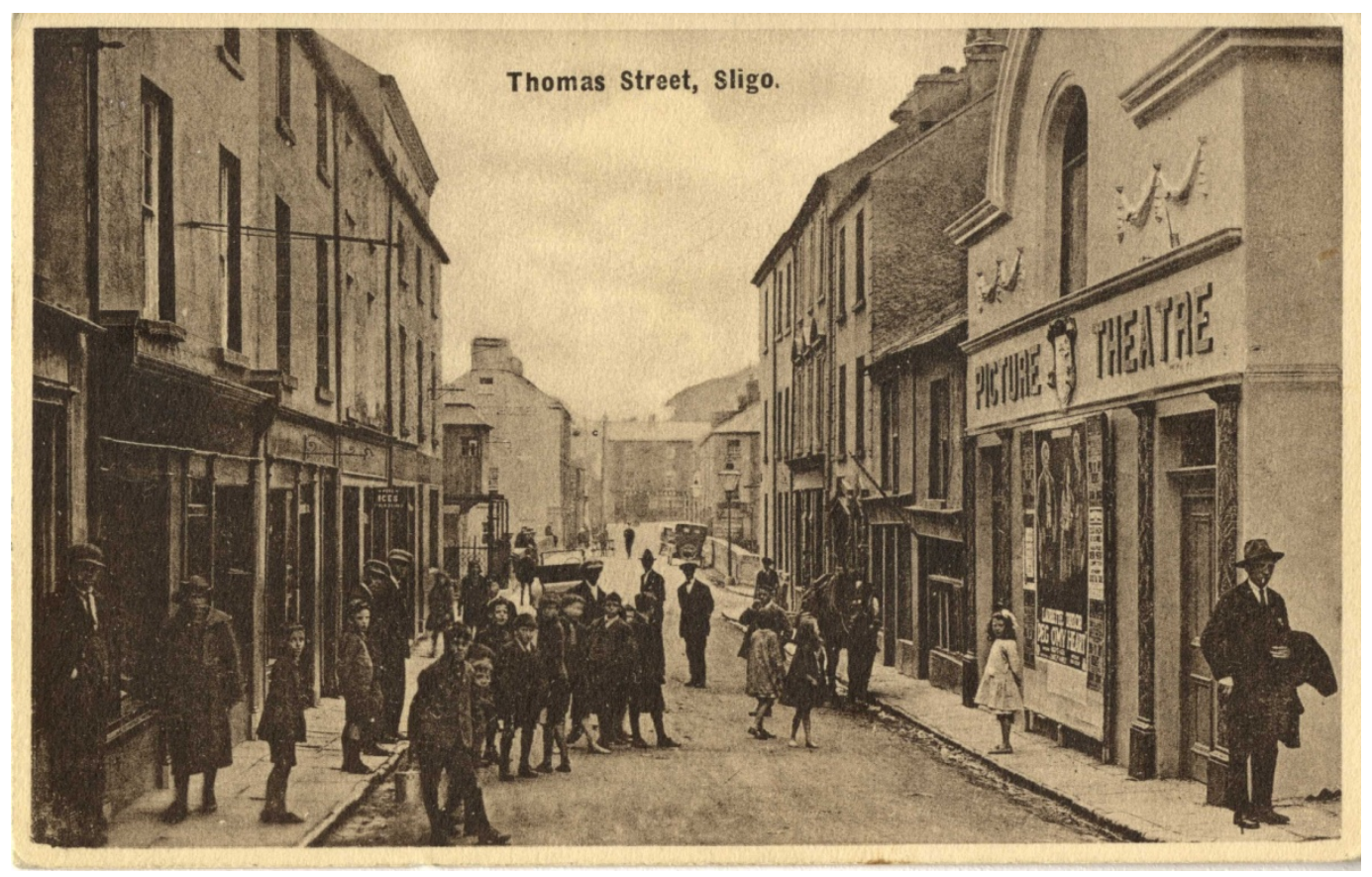

Figure 5. Sligo Picture Theatre in 1924, featuring a poster of Laurette Taylor in Peg o' my heart (Metro, 1922). Courtesy of the Local Studies Collection of Sligo County Library.

Little more can be definitively said about the make-up of the overflowing audience, but contextual details invite speculation. With seats at $3 \mathrm{~d}$ and $6 \mathrm{~d}-$ at least half the cost of a show at the Town-Hall - and just $2 \mathrm{~d}$ for children, its pricing policy seems to have been judged both to allow those with just the minimum of disposable income to attend at least occasionally as well as to encourage more frequent return visits by others. Beginning in March 1913, the Kilgannons shot and exhibited local films of such events as the laying of the foundation stone to the memorial of nationalist politician P. A. McHugh and the bitter strike at Sligo port, films that attracted large audiences (Anon. 1913b, 1913c, 1913d). How the audience reacted to these films of nationalist remembrance and labour unrest, or even who the audience was for these or other films, remains unclear. A surviving image of the Picture Theatre is striking not only for the details of the facade and adjacent buildings but particularly for the groups of adults and children assembled in the street (Figure 5), but as it dates to July 1924, shortly after the premises had been refurbished, it tells us little about the Picture Theatre's audience from the early 1910s.

Nevertheless, this cinema survived beyond its first decade as a healthy and growing business, so that it came to occupy an ever-more prominent place on Sligo's streetscape. The few details that survive about the establishment and early years of the Picture Theatre allows us to conclude that it was a small-scale venture by a family in a cognate business providing daily filmed

entertainment of a kind that had never existed before for the working class of the town and only occasionally for the better off.

Consideration of the Gillooly Hall, the Sligo Picture Theatre's rival film venue, suggests that what may appear to be tantalizing glimpses of working class solidarity or nationalist resistance may instead be occasions of social control by the Catholic nationalist middle class. Figure 6 features a cutting from the Sligo Champion in September 1912 in which the two picture shows advertised special attractions side-by-side, something that rarely happened because the Gillooly Hall did not generally advertise but could rely on regular and extensive newspaper coverage. On the right, the Sligo Picture Theatre promoted its special attraction, the Irish-shot 'O'Kalem' onereeler 'You remember Ellen' (Kalem, 1911), which was an adaptation of a song of the same name by the nineteenth-century Irish national poet Thomas Moore. On two nights of its three-night run, the song itself would be sung by Robert Smyllie, a town councillor and editor of the Sligo Times, who was an award-winning singer. This was not Smyllie's first engagement in picture 
accompaniment; he had also sung 'The death of Nelson' at a screening of The Battle of Trafalgar (Edison, 1911) in the Gillooly Hall in December 1911 (Anon. 1911d). These engagements by Smyllie suggest that both film shows could be considered respectable, had become firmly integrated into the town's entertainment circuits and, indeed, offered an interchangeable entertainment. The left-hand side of the page contains an announcement of the resumption of the cinematograph performances at the Gillooly Hall which had stopped during July and August but were resuming for the autumn and winter season. For the first time, these venues would be competing directly with each other because both were mounting shows every night of the week; up to this point, the Gillooly Hall had screened on just two or three nights. The existence of rival shows every night of the week is indicative of the increasing interest that local exhibitors sensed - and indeed had fostered - in Sligo. A third film venue, the Rink Picture Palace,would open in March 1913.

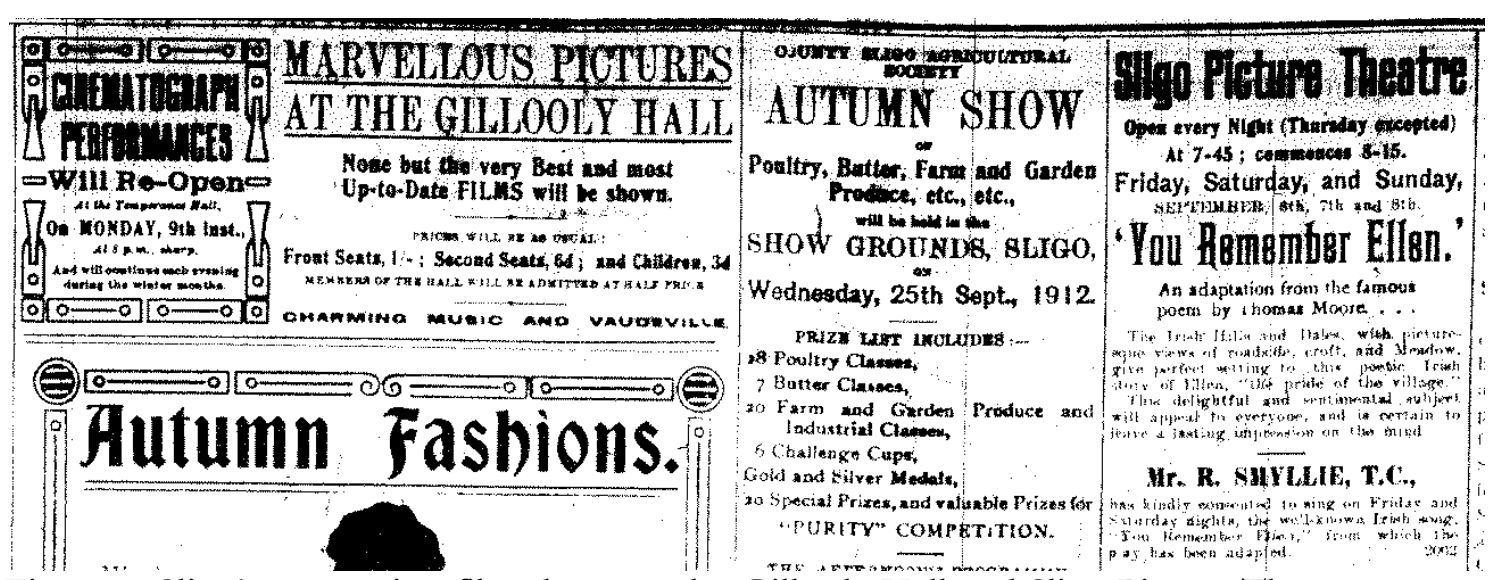

Figure 6. Sligo's competing film shows at the Gillooly Hall and Sligo Picture Theatre were rarely advertised together, as they are here in the Sligo Champion, 2 September 1912.

What makes the film shows at the Gillooly Hall particularly interesting is that they are evidence at this crucial period of cinema becoming not only Irish and local but also Catholic. This is extraordinary in an Irish context in which the Catholic Church's active association with early cinema is generally seen as limited to the ultimately successful campaign for the strict censorship of films. As cinema came to constitute an institution all over Ireland, it took some time for the church to develop a coherent response, and the active involvement in the exhibition of films in Sligo was one manifestation of this. The Gillooly Hall's full title was the Gillooly Memorial Temperance Hall, named after Catholic bishop Laurence Gillooly. The Protestant Church of Ireland was also very active in promoting temperance in Sligo, but Sligo's population was 83 percent Catholic, and it showed its commitment to the cause of temperance by contributing to the construction of the Gillooly Hall, a substantial edifice that opened in 1903. It was essentially a social club that provided a range of activities from billiards and cards to a reading room and Irish dancing classes, all designed to keep its members occupied in the evenings and out of pubs. That the purpose of the Gillooly hall was specifically to control the leisure of the working classes was unambiguously stated by the incumbent bishop John Joseph Clancy, in an address to a meeting at the Hall in September 1911. 'The housing conditions of working men in Sligo', Clancy noted,

were, as a rule, so wretched, so devoid of home comfort, so calculated to drive them elsewhere for consolation, that they deemed it imperative to provide this Hall in order to furnish innocent means of recreation and relaxation and intellectual improvement - with all the reasonable comforts of a happy home - for the working men of the town (Anon. 1911e). 
Following the success of film shows at the hall in the summer of 1911, the organizing committee, led by Father Bernard Crehan, made alterations to the building to house a projector and arranged seating for 600 patrons to provide regular film screenings (Anon. 1911f; Anon. $1911 \mathrm{~g})$. These shows were open to non-members who had to pay double the price $-1 \mathrm{~s}$ and $6 \mathrm{~d}$ rather than the $6 \mathrm{~d}$ and $3 \mathrm{~d}$ for members. One of the benefits of membership, then, was that one could attend a film show at the hall for the same price as at the Picture Theatre. As its film shows gained in popularity over the winter season of 1911-12, Crehan clearly saw the shows as a particularly lucrative and effective way of attracting those who were otherwise uninterested in temperance. Indeed, the programmes displayed no preference for temperance-themed films and were identical to those at the Picture Theatre and at other early cinemas around the country. Crehan seems to have been happy to leave the programming to Michael Tighe, the hall's projectionist (Figure 7). 'The motion-picture entertainments are under the able direction of Mr. Michael J. Tighe', commented the fan magazine The Pictures, 'whose one ambition is to please even the most critical patrons by showing the best photoplays procurable, and the best only' (Anon. 1912b). Tighe would leave Sligo in late 1913 and subsequently become one of Ireland's best-known exhibitors.



Figure 7. Michael Tighe's influence on programming at the Gillooly Hall meant that film shows there demonstrated no preference for temperance titles and instead offered the best available films. The Pictures 25 May 1912. Courtesy of The Bill Douglas Cinema Museum, University of Exeter.

This programming policy seems to have been a particular intervention into the politics of the town in the early 1910s rather than just an attempt to provide popular recreation that would attract working-class people away from the pubs. The alarming elsewhere to which Bishop Clancy was concerned that the wretchedness of living conditions was driving Sligo's working 
class in the autumn of 1911 was not primarily the pub but the union hall. A branch of James Larkin's Irish Transport and General Workers' Union was founded in Sligo and would be the catalyst over the next three year for substantial victories by workers at the expense of employers. Speaking as the union branch was being founded, Clancy deplored the light-hearted indifference with which [workers] turned their backs on [the Temperance] institution and set up rival halls at the suggestion of every mountebank and quidnunc that comes the way' (Anon. 1911e). Such concerns about the emergence of class politics were widely aired in the press by other representatives of Irish interests, such as the editor of the nationalist Sligo Champion, who commented that ' $\mathrm{w}$ ] $\mathrm{e}$ have been fighting for years for self-government; now when it is within our grasp we are plainly informed that when [nationalist leader John] Redmond gets Home Rule he will have to settle accounts with Jim Larkin!' (Anon. 1911h). For Clancy and others, the new forms of union organization were more unwelcome an import into Sligo than the cinema. Indeed, the cinema could be an effective distraction from the kind of working-class sociability that led to effective political action.

Therefore, in Sligo, cinema was born again - if that phrase is not too inappropriately evangelical - partly through the proselytizing efforts of the Catholic Church to convert the town's working class from drinking and trade unionism to cinemagoing. To put this another way, the cinema was constituted as an institution in the town through the hegemonic struggles of other institutions, particularly through the efforts of the Catholic Church and mainstream nationalism to suppress organized labour. For the cinema to be used in this way, of course, it was necessary - to paraphrase Gaudreault and Marion - for the stork of the 1910s to deliver an institution fully formed - or at least highly developed - in the sectors of production and distribution, and with suitable models of exhibition and reception that could be adopted or imposed locally. In general, exhibition and reception were necessarily the least fully formed sectors of the nascent cinematic institution, and they were most directly exposed to and - to varying extents - produced by local condition. The cinema certainly transformed leisure in Irish provincial towns by providing affordable professionally made entertainment every night of the week, but cinema's constitution in Sligo suggests that its institutional meanings should not be sought in its relative equality of access or in filmic images of peasants that suggest the importance of subaltern classes. For Sligo's Catholic Church and parliamentary nationalists, what appeared on the screen was of little consequence, provided that it kept workers out of the pubs and union hall. With the focus on Irish labour history during 2013 centenary of the industrial dispute known as the Dublin Lockout, it is salutary to be reminded how institutional factors can undermine the apparent democratic potential of new media.

\section{References}

Anon. 1911a. "The Irish census". Sligo Independent, 3 June 1911.

Anon. 1911b. "Sligo picture theatre". Advertisement. Sligo Times, 16 December 1911.

Anon. 1911c. "Amusements: Sligo picture theatre". Sligo Independent, 30 December 1911.

Anon. 1911d. "Kinematograph entertainment". Sligo Champion, 9 December 1911.

Anon. 1911e. "The Gillooly hall”. Sligo Champion, 28 October 1911.

Anon. 1911f. "Sligo temperance hall”. Sligo Times, 9 September 1911.

Anon. 1911g. "Kinematograph entertainments". Sligo Independent, 21 October 1911.

Anon. 1911h. "Socialism condemned". Sligo Champion, 28 October 1911.

Anon. 1912a. "Though your sins be as scarlet". Sligo Champion, 31 August 1912.

Anon. 1912b. "Picture theatres and their managers". The Pictures 25 May: 13.

Anon. 1913a. "Sligo picture theatre". Sligo Times, 4 January 1913.

Anon. 1913b. "Sligo picture theatre". Sligo Times, 22 March 1913.

Anon. 1913c. "Sligo picture theatre". Sligo Champion, 22 March 1913.

Anon. 1913d. "Sligo picture theatre". Sligo Times, 29 March 1913. 
Bayliss, Gail. "Exchanging looks: Gap girls and colleens in early Irish tourist photography". Early Popular Visual Culture 10 (4): 325-43.

Brown, Richard. 2004. "New century pictures: Regional enterprise in early British film exhibition". In The lost world of Mitchell and Kenyon: Edwardian Britain on film, ed. Vanessa Toulmin, Simon Popple and Patrick Russell, 69-82. London: BFI.

Campbell Ross, Ian, ed. 1986. Public virtue, public love: The early years of the Dublin lying-in hospital. Dublin: O’Brien.

Census of Ireland, 1901/1911. National Archives of Ireland. http://census.national archives.ie.

Cinema News and Property Gazette. 1915. Year Book and Diary for 1915. London: Cinema House.

Condon, Denis. 2008. Early Irish cinema, 1895-1921. Dublin, Irish Academic Press.

Condon, Denis. 2010. “'Limelight on the Colleen Bawn': Resisting autoexoticism in provincial Irish picture houses in the early 1910s". In Peripheral early cinema: Domitor 2008, ed. François Amy de la Bretèque, et al., 245-55. Perpignan: Presses Universitaires de Perpignan.

Frawley, Oona, ed. 2011. Memory Ireland: History and Modernity. Syracuse: Syracuse University Press.

Gaudreault, André. 2000. "The diversity of cinematographic connections in the intermedial context of the turn of the $20^{\text {th }}$ century". In Visual delights: Essays on the popular and projected image in the $19^{\text {th }}$ century, ed. Simon Popple and Vanessa Toulmin, 8-15. Trowbridge: Flicks Books.

Gaudreault, André, and Philippe Marion. 2005. "A medium is always born twice...”. Early Popular Visual Culture 3 (1): 3-15.

Maltby, Richard, and Melvyn Stokes. 2007. "Introduction". In Going to the movies: Hollywood and the social experience of cinema, ed. Richard Maltby, Melvyn Stokes and Robert C. Allen, 1-22. Exeter: University of Exeter Press.

Maltby, Richard. 2011. "New cinema histories". In Explorations in new cinema history: Approaches and case studies, ed. Richard Maltby, Daniel Biltereyst and Philippe Meers, 3-40. Chichester: Wiley-Blackwell.

Marx, Karl. 1978. “The eighteenth Brumaire of Louis Napoleon”. In The Marx-Engels reader, ed. Robert C. Tucker, 594-614. New York: Norton.

McTernan, John C. 2000. A Sligo miscellany: A chronicle of people, places \& events of other days. Sligo: Avena.

The O'Kalem collection. Directed by Peter Flynn. Dublin: Irish Film Institute/BIFF, 2010.

Paddy. 1913. "Pictures in Ireland". The Bioscope 27 November: 854.

Rockett, Kevin, and Emer Rockett. 2011. Magic lantern, panorama and moving picture shows in Ireland, 1786-1909. Dublin: Four Courts Press.

\section{Notes}

${ }^{1}$ Although they are not very explicit in establishing 1910 as the year of the second birth of cinema, this date is mentioned when they favourably cite Rick Altman's comment on the end of cinema's intermedial phase (Gaudreault and Marion 15n10), and it will be familiar to those conversant with Gaudreault's earlier account of the move from an intermedial cinema to institutional cinema (Gaudreault 2000, 12).

${ }^{2}$ The seven surviving O'Kalem film have recently become available on a two-disc DVD that also offers an informative documentary (O'Kalem 2010). 
3 The earlier manifestation of the colleen in tourist photographs of Killarney has recently been thoroughly analyzed here by Gail Bayliss (2012). 